\title{
Brazing of Boron Carbide by Cu-Alloys: Interface Interaction and Mechanical Properties of Joints
}

\author{
Michael Aizenshtein ${ }^{1}$, Shay Silhov ${ }^{1,2}$, Natalya Froumin ${ }^{2} \&$ Nachum Frage $^{2}$ \\ ${ }^{1}$ NRC-Negev, Beer-Sheba, Israel \\ ${ }^{2}$ Department of Materials Engineering, Ben-Gurion University, Beer-Sheba, Israel \\ Correspondence: Michael Aizenshtein, NRC-Negev, P.O. Box 9001, Beer-Sheba 84190, Israel. Tel: \\ 972-8-656-7196. E-mail: aizensht@bgu.ac.il
}

Received: September 11, $2012 \quad$ Accepted: October 22, $2012 \quad$ Online Published: November 11, 2012

doi:10.5539/jmsr.v2n1p42

URL: http://dx.doi.org/10.5539/jmsr.v2n1p42

\begin{abstract}
Boron carbide is one of the most promising structural ceramics; therefore its joining to other ceramics and metals is of technological importance. In this study, interface interactions and joints strength were studied in various cases of $\mathrm{B}_{4} \mathrm{C} / \mathrm{Cu}$ based fillers $\left(\mathrm{Cu}-9 \mathrm{at} \% \mathrm{~B}, \mathrm{Cu}-4.5 \mathrm{at} \% \mathrm{Ti}\right.$ and Ticusil $\left.{ }^{\circledR}\right)$. The fillers partially wet $\mathrm{B}_{4} \mathrm{C}\left(\theta<50^{\circ}\right)$, but the interface composition and morphology are different. In the $\mathrm{B}_{4} \mathrm{C} / \mathrm{Cu}-9$ at. $\% \mathrm{~B}$ system no new phases are detected at the interface, while the formation of $\mathrm{TiB}_{2}$ takes place in the case $\mathrm{B}_{4} \mathrm{C} / \mathrm{Cu}-4.5 \mathrm{at} \% \mathrm{Ti}$, and a double layer containing $\mathrm{TiB}_{2}$ and $\mathrm{TiC}$ is formed at the $\mathrm{B}_{4} \mathrm{C} /$ Ticusil ${ }^{\circledR}$ interface.

The maximal shear stress for $\mathrm{B}_{4} \mathrm{C} / \mathrm{B}_{4} \mathrm{C}$ joints breakage was obtained for the $\mathrm{Cu}-9$ at.\%B brazing alloy which displays partial wetting without the formation of brittle phases at the ceramic/metal interface.

This study shows that improved wetting is essential but not sufficient in order to obtain strong bonding between $\mathrm{B}_{4} \mathrm{C}$ and the fillers examined.
\end{abstract}

Keywords: brazing, boron carbide, thermodynamics, mechanical properties, interfaces

\section{Introduction}

Successful performance of structural ceramic components depends on the quality and reliability of ceramic-to-ceramic and ceramic-to-metal joints. Direct brazing using active filler metals is one technique that can fulfill such requirements. In order to minimize the effect of thermal stresses it is desired to develop brazing alloys with relatively low melting temperature (based on $\mathrm{Cu}$ for instance), which display appropriate wetting properties. Adequate wetting of boron carbide may be achieved by using active brazing alloys. Yet, the major drawback of $\mathrm{B}_{4} \mathrm{C}$ is related to its' low coefficient of thermal expansion $\left(4-8 \cdot 10^{-6} \mathrm{~K}^{-1}\right)$ compared to brazing metals $\left(16.6 \cdot 10^{-6} \mathrm{~K}^{-1}\right.$ and $19.1 \cdot 10^{-6} \mathrm{~K}^{-1}$ for $\mathrm{Cu}$ and $\mathrm{Ag}$, respectively) which might cause residual stresses at the interface (Naidich et al., 2008). The results of a systematical investigation of boron carbide wettability by various metals were reported in previous publications (Froumin et al., 2003; Frage et al., 2004; Aizenshtein et al., 2005a; Aizenshtein et al., 2005b; Aizenshtein et al., 2008a; Aizenshtein et al., 2008b) and the wetting mechanism is well understood. Experimental results for $\mathrm{Ti}$ and $\mathrm{B}$ alloyed $\mathrm{Cu}$ and $\mathrm{Ti}$ alloyed $\mathrm{Ag}$ are presented in Figure 1. In the $\mathrm{B}_{4} \mathrm{C} /(\mathrm{Cu}, \mathrm{Ag})-\mathrm{Ti}$ systems, the improved wetting is achieved due to the formation of new phases at the interface, while in the $\mathrm{B}_{4} \mathrm{C} / \mathrm{Cu}-\mathrm{B}$ system, the contact angle decreases as a result of the composition shift of boron carbide towards higher boron contents (Froumin et al., 2003).

In the present work the mechanical properties of brazed boron carbide using three $\mathrm{Cu}$-based fillers, namely $\mathrm{Cu}-9$ at.\%B, Cu-4.5at.\%Ti and commercial Ticusil® alloy (68.8wt.\% Ag, 26.7wt.\% Cu, 4.5wt.\% Ti) were investigated in order to clarify the correlation between the interface structure and mechanical properties of the joints. 




Figure 1. The final contact angle in the $\mathrm{B}_{4} \mathrm{C} /(\mathrm{Cu}-\mathrm{B}), \mathrm{B}_{4} \mathrm{C} /(\mathrm{Cu}-\mathrm{Ti})$ and $\mathrm{B}_{4} \mathrm{C} /(\mathrm{Ag}-\mathrm{Ti})$ systems after $30 \mathrm{~min}$ at 1423K (Aizenshtein et al., 2005a; Froumin et al., 2003)

\section{Experimental Procedure}

Two parts of $\mathrm{B}_{4} \mathrm{C}\left(15 \times 5 \times 5 \mathrm{~mm}^{3}\right.$ and $\left.5 \times 5 \times 5 \mathrm{~mm}^{3}\right)$ were cut from a block $(99.8 \%$ of the theoretical density). The surfaces of the samples were polished down to $1 \mu \mathrm{m}$ using a $\mathrm{SiC}$ paper and diamond paste and cleaned ultrasonically in ethanol. Three types of brazing alloys were used in this study: $\mathrm{Cu}-9 \mathrm{at} . \% \mathrm{~B}, \mathrm{Cu}-4.5 \mathrm{at} . \% \mathrm{Ti}$ and the commercial Ticusil ${ }^{\circledR}$. The $\mathrm{Cu}-9 \mathrm{at} . \% \mathrm{~B}$ and $\mathrm{Cu}-4.5 \mathrm{at} . \% \mathrm{Ti}$ alloys were prepared in an arc furnace and rolled down to a final thickness of $150 \mu \mathrm{m}$. The Ticusil ${ }^{\circledR}$ brazing alloy was received in the form of a rolled plate with a thickness of $250 \mu \mathrm{m}$. The rolled sheet was cut to $5 \times 5 \mathrm{~mm}^{2}$ squares and placed between $\mathrm{B}_{4} \mathrm{C}$ specimens. Brazing procedure was performed in a vacuum furnace under $2 \cdot 10^{-3} \mathrm{~Pa}$. Brazed samples were heated to approximately $50^{\circ} \mathrm{C}$ above the melting temperature of the brazing alloys, at the heating rate of $10^{\circ} \mathrm{C} / \mathrm{min}$ and held for 30 minutes at the set point temperature. The cooling rate was about $30^{\circ} \mathrm{C} / \mathrm{min}$.

The maximum load value for joints brakeage was determined using an Instron LRX Plus instrument with the strain rate of $2 \mathrm{~mm} / \mathrm{min}$. Four samples for each brazing alloys were tested.

The microstructure and the composition of the interfaces were examined using optical microscopy and scanning electron microscopy (SEM) equipped with Energy Dispersive (EDS) and Wavelength Dispersive (WDS) Spectrometers.

\section{Results and Discussion}

\subsection{Interface Characterization of the $B_{4} C$ Joints}

General view of the specimens after brazing and their SEM (SE and BSE) images are presented in Figures 2-5. For $\mathrm{Cu}-9$ at.\%B joined $\mathrm{B}_{4} \mathrm{C}$, the interface of the ceramic specimens remains flat and no evidence of new phases was detected (Figure 3). This observation is in a good agreement with the previously reported results on the wetting behavior in the $\mathrm{B}_{4} \mathrm{C} / \mathrm{Cu}-\mathrm{B}$ system (Froumin et al., 2003).

The structure of the $\mathrm{B}_{4} \mathrm{C}$ joint obtained by using $\mathrm{Cu}$-Ti filler (Figure 4) indicates the formation of small craters, which reflect boron carbide dissolution in the melt. According to WDS analysis, the continuous layer (up to $\sim 5 \mu \mathrm{m}$ thick) is $\mathrm{TiB}_{2}$ which was formed as a result of the interaction between dissolved $\mathrm{B}$ and $\mathrm{Ti}$ in the melt. Yet, this layer is detached from the $\mathrm{B}_{4} \mathrm{C} / \mathrm{Cu}$-Ti interface. These observations are similar to that reported for interface interactions in the $\mathrm{B}_{4} \mathrm{C} / \mathrm{Cu}-\mathrm{Ti}$ system (Aizenshtein et al., 2005a).

For the Ticusil ${ }^{\circledR}$ filler the dissolution of $\mathrm{B}_{4} \mathrm{C}$ in the melt was not observed and only a thin (less than $1 \mu \mathrm{m}$ ) continuous Ti-rich layer was formed at the interface (Figure 5). 
(a)
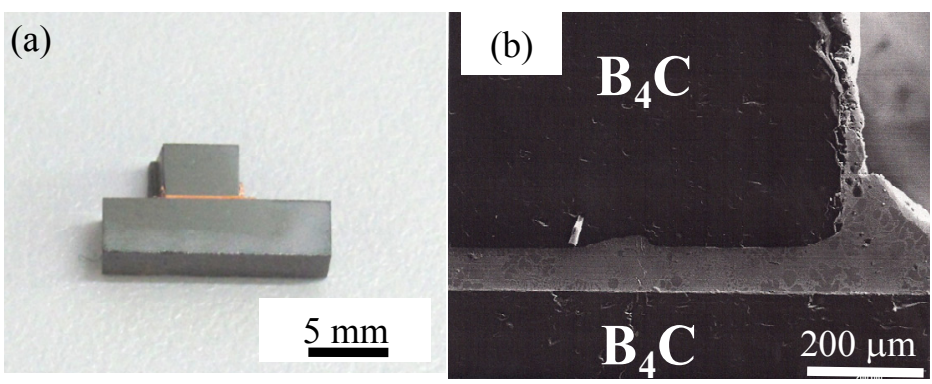

Figure 2. $\mathrm{B}_{4} \mathrm{C}$ after brazing (a) macroscopic image $\mathrm{Cu}-4.5$ at.\%Ti brazed $\mathrm{B}_{4} \mathrm{C}$ (b) $\mathrm{SE}$ image, Ticusil ${ }^{\circledR}$ brazed $\mathrm{B}_{4} \mathrm{C}$

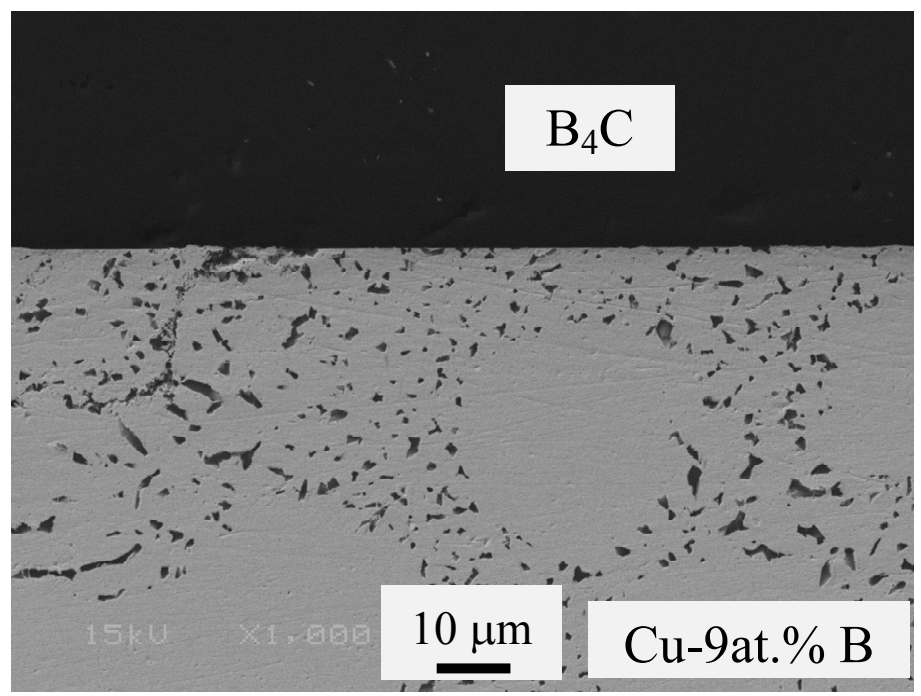

Figure 3. $\mathrm{BSE}$ image of $\mathrm{B}_{4} \mathrm{C}$ specimens joined by $\mathrm{Cu}-9$ at. $\% \mathrm{~B}$ filler alloy

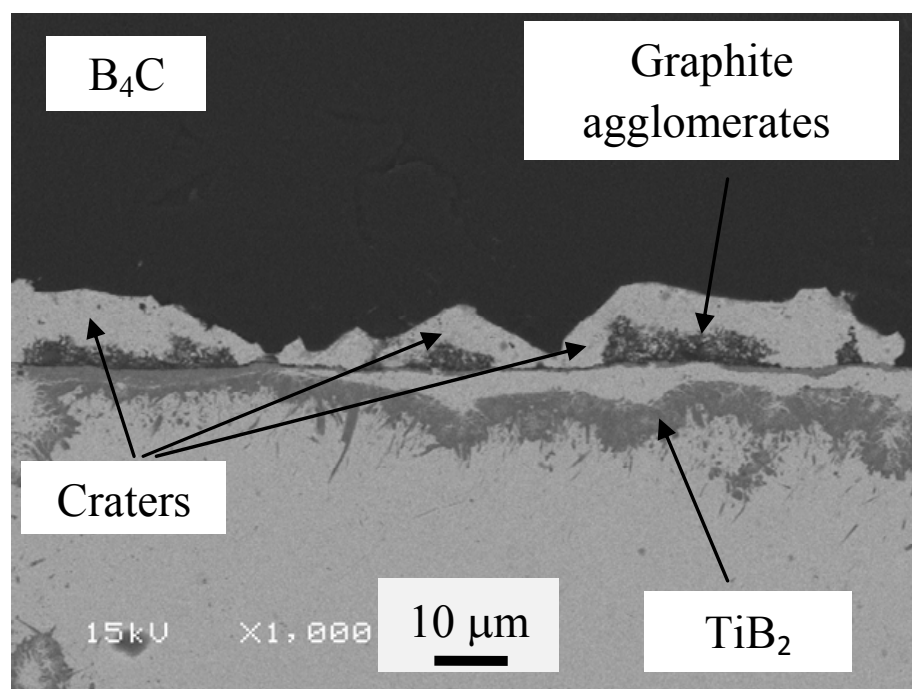

Figure 4. BSE image of $\mathrm{B}_{4} \mathrm{C}$ specimens joined by $\mathrm{Cu}-4.5$ at.\%Ti filler alloy 


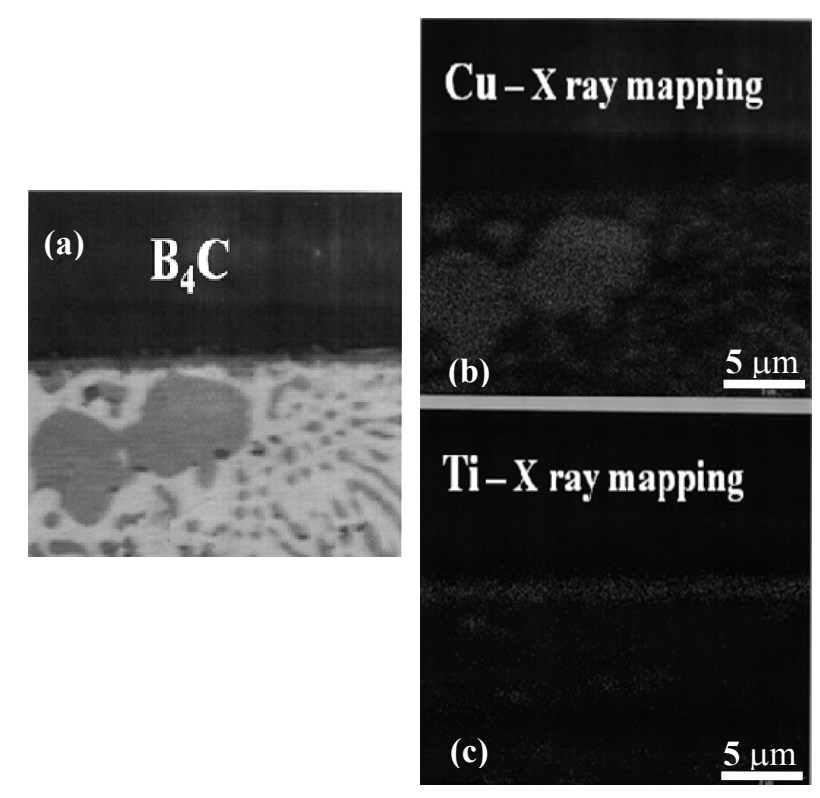

Figure 5. The morphology and spatial distribution of $\mathrm{Cu}$ and $\mathrm{Ti}$ at the $\mathrm{B}_{4} \mathrm{C} /$ Ticusil ${ }^{\circledR}$ interface (a) BSE image, (b) $\mathrm{Cu}$ X-ray mapping, (c) Ti X-ray mapping

According to the WDS line scan across the interface (Figure 6), the composition of this layer, close to the ceramic could be attributed to the $\mathrm{TiB}_{2}$ phase, while TiC sub-layer is in contact with the melt. The same feature was reported for the $\mathrm{B}_{4} \mathrm{C} / \mathrm{Ag}$-Ti system (Aizenshtein et al., 2005a). The formation of such double layer structure at the ceramic-filler interface was also observed in other systems (see for instance Mandal et al., 2004; Kar et al., 2007; Kar \& Ray, 2007).

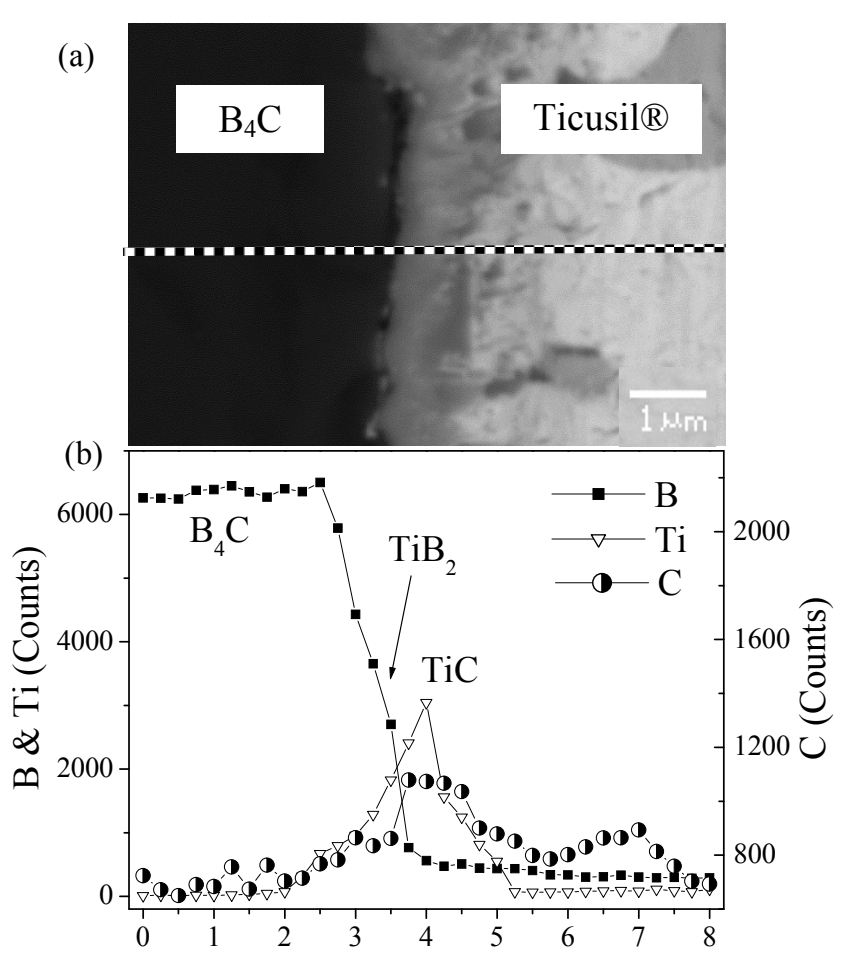

Figure 6. Microstructure and elements distribution at the $\mathrm{B}_{4} \mathrm{C} /$ Ticusil ${ }^{\circ}$ interface (a) BSE image of the scanned area (b) WDS line scans of B, Ti and $\mathrm{C}$ across the interface 
We suggest that the differences between interface morphology in the $\mathrm{B}_{4} \mathrm{C} / \mathrm{Cu}-\mathrm{Ti}$ and $\mathrm{B}_{4} \mathrm{C} /$ Ticusil ${ }^{\circledR}$ systems reflect the thermodynamic properties of the fillers. The solubility of carbon in the liquid metals $(\mathrm{Cu}$ and $\mathrm{Ag})$ is extremely low (Oden \& Gokcen, 1992; Karakaya \& Thompson, 1988). The solubility of $\mathrm{B}$ in liquid $\mathrm{Cu}$ at $1070^{\circ} \mathrm{C}$ is about 20at.\%, while this value for Ag is negligible (Chakrabarti \& Laughlin, 1982; Okamoto, 1992). Thus, the dissolution of boron carbide in liquid $\mathrm{Cu}$ leads to boron transfer to the melt, which reacts with $\mathrm{Ti}$ and forms $\mathrm{TiB}_{2}$, and free carbon precipitation. The dissolution of boron carbide in liquid Ag is very limited. Thus, we assume that the interface morphology in the $\mathrm{B}_{4} \mathrm{C} /$ Ticusil ${ }^{\circledR}$ systems reflects the effect of $\mathrm{Ag}$ on the interface interaction. This assumption could be supported by thermodynamic considerations.

The boron activity in liquid Ag-Cu (Figure 7) was calculated using the Redlich-Kister approach. The interaction parameter, $\mathrm{L}^{0}$, of the $\mathrm{Ag}-\mathrm{B}$ and $\mathrm{Cu}-\mathrm{B}$ liquid solutions was estimated using the binary phase diagrams (Okamoto et al., 1992; Froumin et al., 2003). At 1423K, the values of $\mathrm{L}^{0}$ of the $\mathrm{Cu}-\mathrm{B}$ and $\mathrm{Ag}-\mathrm{B}$ systems are $20 \mathrm{~kJ} / \mathrm{mol}$ and 90 $\mathrm{kJ} / \mathrm{mol}$ respectively. The interaction parameters, $\mathrm{L}^{0}$ and $\mathrm{L}^{1}$, of the $\mathrm{Ag}$-Cu liquid system were reported by Hayes, Lukas, Effenberg and Petzow (1986). Boron activity in $\mathrm{Ag}-\mathrm{Cu}$ alloys is significantly higher than that in pure liquid $\mathrm{Cu}$ and provides the conditions for the formation of a continuous $\mathrm{TiB}_{2}$ layer, attached to the ceramic, which was clearly observed in the case of $\mathrm{B}_{4} \mathrm{C} /$ Ticusil ${ }^{\circledR}$ system (Figure 6). The formation of the double layered morphology is attributed to the Ti interaction with released free carbon resulting in the formation of the titanium carbide phase as was explained by Aizenshtein et al. (2005a).

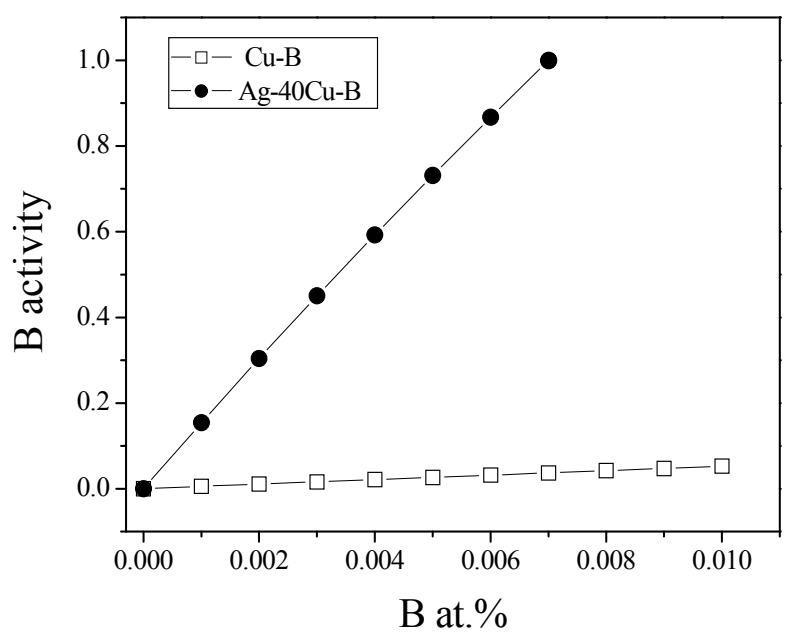

Figure 7. Boron activity in $\mathrm{Cu}$ and $\mathrm{Ag}-40 \mathrm{at} . \% \mathrm{Cu}$ liquid solutions as a function of $\mathrm{B}$ content. The B activity was calculated using Reldlich-Kister approach

\subsection{Joint Strength and its Relation to Microstructure of the Interface}

The mechanical properties strongly depend on the interface structure and residual stresses developed at the interface due to differences of thermal expansion coefficients (CTE). The measured shear forces and stresses for joints brakeage are presented in Table 1. The results obtained for $\mathrm{Cu}-9 \mathrm{at} . \% \mathrm{~B}$ are in the range of the results (131MPa) reported for Fe-Ni-Co/ $\mathrm{Al}_{2} \mathrm{O}_{3}$ joints brazed with Ticusil® (Do Nascimento et al., 1999).

Table 1. Measured shear force for different joints

\begin{tabular}{ccc}
\hline Brazing alloys & $\begin{array}{c}\text { Shear force, } \\
\mathrm{kN}\end{array}$ & $\begin{array}{c}\text { Calculated shear stress } \\
{[\mathrm{MPa}]}\end{array}$ \\
\hline Ticusil ${ }^{\circledR}$ & $0.59 \pm 0.15$ & $23.6 \pm 6.0$ \\
$\mathrm{Cu} 4.5$ at.\%Ti & $0.76 \pm 0.04$ & $30.4 \pm 1.6$ \\
$\mathrm{Cu}$ 9at.\%B & $2.44 \pm 0.27$ & $97.6 \pm 10.8$ \\
\hline
\end{tabular}


Failure of the $\mathrm{B}_{4} \mathrm{C} / \mathrm{Cu}-9 \mathrm{at} \% \mathrm{~B}$ joints take place due to a crack propagation in boron carbide (Figure $8 \mathrm{a}$ ), while failure of the $\mathrm{B}_{4} \mathrm{C} / \mathrm{Ticusil}{ }^{\circledR}$ and $\mathrm{B}_{4} \mathrm{C} / \mathrm{Cu}-4.5$ at $\% \mathrm{Ti}$ joints occur through the brazing alloy (Figure $8 \mathrm{~b}$ ). The fracture path through the boron carbide body reflects a strong bonding at the metal/ceramic interface and the fact that the boron carbide composition at the interface is modified during the brazing process.

(a)

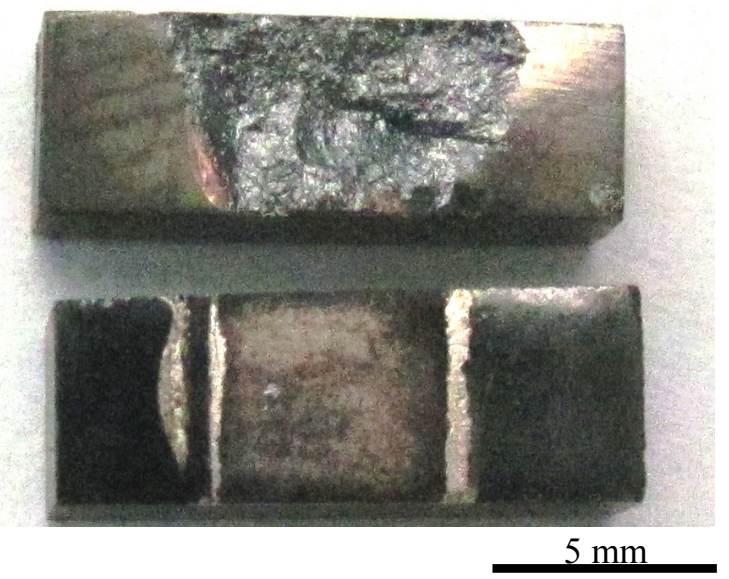

Figure 8. $\mathrm{B}_{4} \mathrm{C}$ joints after shear force measurements (a) Cu-9at.\%B brazing alloy (b) Ticusil $®$ brazing alloy

In the two other cases the interface is weaker. In the case of $B_{4} C /$ Ticusil ${ }^{\circledR}$, the weakening of the interface is directly correlated to the formation of the new brittle phases $\mathrm{TiB}_{2}$ and $\mathrm{TiC}$. In the case of $\mathrm{B}_{4} \mathrm{C} / \mathrm{Cu}-4.5 \mathrm{at} \% \mathrm{Ti}$, the brittle $\mathrm{TiB}_{2}$ phase was detached from the interface and the weak interface is a result of the poor bonding between $\mathrm{B}_{4} \mathrm{C}$ and $\mathrm{Cu}$.

In this study it is demonstrated that improved wetting properties are essential, but not sufficient in order to guarantee adequate bonding. In fact, the contact angle in the $\mathrm{B}_{4} \mathrm{C} / \mathrm{Cu}-\mathrm{B}$ is the highest compared to $\mathrm{B}_{4} \mathrm{C} /(\mathrm{Cu}, \mathrm{Ag})-\mathrm{Ti}$ systems (Figure 1), yet better joint strength was obtained in the first case.

\section{Conclusion}

Joining of boron carbide specimens by $\mathrm{Cu}$ based fillers $\left(\mathrm{Cu}-9 \mathrm{at} \% \mathrm{~B}, \mathrm{Cu}-4.5 \mathrm{at} \% \mathrm{Ti}\right.$ and Ticusil $\left.{ }^{\circledR}\right)$ was studied. These alloys wet $\mathrm{B}_{4} \mathrm{C}$ well $\left(\theta<50^{\circ}\right)$, whereas the interface composition and morphology are different. In the $\mathrm{B}_{4} \mathrm{C} / \mathrm{Cu}-9$ at.\%B system no new phases were detected at the interface, while the formation of new brittle phases takes place in the $\mathrm{B}_{4} \mathrm{C} / \mathrm{Cu}-4.5 \mathrm{at} \% \mathrm{Ti}$ and $\mathrm{B}_{4} \mathrm{C} /$ Ticusil ${ }^{\circledR}$ systems. The maximal strength of the joint close to $100 \mathrm{MPa}$ was obtained for the $\mathrm{Cu}-9 \mathrm{at} \% \mathrm{~B}$ filler which could be correlates with the interface composition and structure. This study shows that improved wetting is essential but not sufficient in order to obtain strong bonding between $\mathrm{B}_{4} \mathrm{C}$ and the fillers examined.

\section{References}

Aizenshtein, M., Froumin, N., Frage, N., \& Dariel, M. P. (2005a). Interface interaction and wetting behaviour in $\mathrm{B}_{4} \mathrm{C} /(\mathrm{Me}-\mathrm{Ti})$ systems $(\mathrm{Me}=\mathrm{Cu}, \mathrm{Ag}, \mathrm{Sn}$ and $\mathrm{Au})$. Materials Science and Engineering: A, 395, 180-185. http://dx.doi.org/10.1016/j.msea.2004.12.017

Aizenshtein, M., Froumin, N., Shapiro-Tsoref, E., Dariel, M. P., \& Frage, N. (2005b). Wetting and interface phenomena in the $\mathrm{B}_{4} \mathrm{C} /(\mathrm{Cu}-\mathrm{B}-\mathrm{Si})$ system. Scripta Materialia, 53, 1231-1235. http://dx.doi.org/10.1016/j.scriptamat.2005.08.006

Aizenshtein, M., Froumin, N., Dariel, M. P., \& Frage, N. (2008a). Wetting and interface interactions in the $\mathrm{B}_{4} \mathrm{C} / \mathrm{Al}-\mathrm{Me} \quad(\mathrm{Me}-\mathrm{Cu}, \mathrm{Sn})$ Systems. Materials Science and Engineering: A, 474, 214-217. http://dx.doi.org/10.1016/j.msea.2007.04.002

Aizenshtein, M., Mizrahi, I., Froumin, N., Hayun, S., Dariel, M. P., \& Frage, N. (2008b). Interface Interaction in the $\mathrm{B}_{4} \mathrm{C} /(\mathrm{Fe}-\mathrm{B}-\mathrm{C}) \quad$ system. Materials Science and Engineering: A, 495, 70-74. http://dx.doi.org/10.1016/j.msea.2007.06.100

Chakrabarti, D. J., \& Laughlin, D. E. (1982). The B-Cu (Boron-Copper) system. Journal of Phase Equilibria, 3, 45-48. http://dx.doi.org/10.1007/BF02873410 
Do Nascimento, R. M., Martinelli, A. E., Buschinelli, A. J. DE A., \& Klein, A. N. (1999). Brazing $\mathrm{Al}_{2} \mathrm{O}_{3}$ to sintered Fe-Ni-Co alloys. Journal of Materials Science, 34, 5839-5845. http://dx.doi.org/10.1023/A:1004774621738

Frage, N., Froumin, N., Aizenshtein, M., \& Dariel, M. P. (2004). Interface reaction in the $\mathrm{B}_{4} \mathrm{C} /(\mathrm{Cu}-\mathrm{Si})$ system. Acta Materialia, 52, 2625-2635. http://dx.doi.org/10.1016/j.actamat.2004.02.010

Froumin, N., Frage, N., Aizenshtein, M., \& Dariel, M. P. (2003). Ceramic-metal interaction and wetting phenomena in the $\mathrm{B}_{4} \mathrm{C} / \mathrm{Cu}$ system. Journal of the European Ceramic Society, 23, 2821-2828. http://dx.doi.org/10.1016/S0955-2219(03)00294-2

Hayes, F. H., Lukas, H. L., Effenberg, G., \& Petzow, G. (1986). A Thermodynamic Optimisation of the Cu-Ag-Pb System. Zeitschrift fur Metallkunde, 77(11), 749-754

Kar, A., Mandal, S., Ghosh, R. N., Ghosh, T. K., \& Ray, A. K. (2007). Role of Ti diffusion on the formation of phases in the $\mathrm{Al}_{2} \mathrm{O}_{3}-\mathrm{Al}_{2} \mathrm{O}_{3}$ brazed interface. Journal of Materials Science, 42, 5556-5561. http://dx.doi.org/10.1007/s10853-006-1092-6

Kar, A., \& Ray, A. K. (2007). Characterization of $\mathrm{Al}_{2} \mathrm{O}_{3}-304$ stainless steel braze joint interface. Materials Letters, 61, 2982-2985. http://dx.doi.org/10.1016/j.matlet.2006.10.058

Karakaya, I., \& Thompson, W. T. (1988). The Ag-C (Silver-Carbon) System. Journal of Phase Equilibria, 9 , 226-227. http://dx.doi.org/10.1007/BF02881268

Mandal, S., Rao, V., \& Ray, A. K. (2004). Characterization of the brazed joint interface between $\mathrm{Al}_{2} \mathrm{O}_{3}$ and $\begin{array}{lllll}(\mathrm{Ag}-\mathrm{Cu}-\mathrm{Ti}) . \quad \text { Journal } & \text { Materials } & \text { Science, } & 39 & \end{array}$ http://dx.doi.org/10.1023/B:JMSC.0000039295.03229.25

Naidich, Y. V., Zhuravlev, V. S., Gab, I. I., Kostyuk, B. D., Krasovskyy, V. P., Adamovskyy, A. A., \&Taranets, N. Yu. (2008). Liquid metal wettability and advanced ceramic brazing. Journal of the European Ceramic Society, 28, 717-728. http://dx.doi.org/10.1016/j.jeurceramsoc.2007.07.021

Oden, L. L., \& Gokcen, N. A. (1992). Phase diagrams and thermodynamic properties of C in the alloys from $1550^{\circ} \mathrm{C}$ to $2300^{\circ} \mathrm{C}$. Metallurgical and Materials Transactions B, 23, 453-458. http://dx.doi.org/10.1007/BF02649664

Okamoto., H. (1992). Ag-B (silver-boron). Journal of Phase Equilibria, 13, 211-212. http://dx.doi.org/10.1007/BF02667492 